Volume 3, No. 3, September - December 2018 ISSN: 2503-4235 (p); 2503-4243 (e)

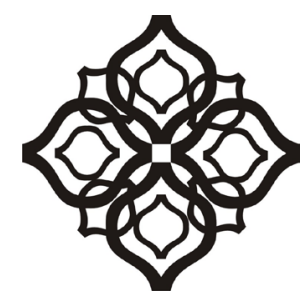

Shirkah

Journal of Economics and Business 


\section{Shirkah}

Journal of Economics and Business

Vol. 3, No. 3, September-December 2018

ISSN: 2503-4235 (p); 2503-4243 (e)

\section{Editor in Chief}

Dwi Condro Triono

\section{Managing Editor}

Jasanta Peranginangin

\section{Editorial Boards}

Abdul Azim Islahi,

Islamic Economics Institute, King Abdulaziz University, Saudi Arabia

Abu Umar Faruq Ahmad,

UBD School of Business and Economics Universiti, Brunei Darussalam

Cedomir Nestorovic,

ESSEC Business School Asia Pacific, Singapore

Fitri Wulandari,

Faculty of Islamic Economics and Business, IAIN Surakarta, Indonesia Johan Fischer,

Department of Social Sciences and Business Roskilde Universitetscenter, Denmark Muhamed Zulkhibri,

Islamic Research and Training Institute, Islamic Development Bank, Saudi Arabia M. Kabir Hassan,

Department of Economics and Finance, University of New Orleans, United States Musa Asy'arie,

Faculty of Islamic Economics and Business, IAIN Surakarta, Indonesia Nunung Nurul Hidayah,

Aston Business School, Aston University, Birmingham, United Kingdom

Saim Kayadibi,

Department of Economics, Kulliyyah of Economics and Management Science, International Islamic University Malaysia, Malaysia 
Shaikh M Ghazanfar,

Departement of Economics, University of Idaho, Russian Federation

Sigit S. Wibowo,

Department of Management, Faculty of Economics and Business, Universitas Indonesia, Indonesia

Vihang R. Errunza,

Desmarais Global Finance Research Centre, Desautels Faculty and Management, McGill University, Canada

\section{Assistant to Editor}

M. Endy Saputro

M. Zainal Anwar

Shirkah Journal of Economics and Business is a peer-reviewed journal published three times a year (January-April, May-August and September-December) by Faculty of Islamic Economics and Business, Institut Agama Islam Negeri (IAIN) Surakarta Central Java, Indonesia. The main objective of Shirkah is to offer an academic space of exchange ideas and initiate the increase number of qualified article produced by postgraduate students, practitioners and academicians.

\section{Editorial Office}

Ruang Jurnal Shirkah

Lantai Dasar, Sayap Barat, Fakultas Ekonomi dan Bisnis Islam, IAIN Surakarta

Jln. Pandawa No. 1, Kartasura, Sukoharjo, Jawa Tengah Kode Pos. 57168

Phone (+62271) 781516 Fax: (+62271)782336

E-mail: shirkahjournal@iainsurakarta.ac.id; shirkahiainsurakarta@gmail.com Website: http://shirkah.or.id/ 


\section{Shirkah}

\section{Journal of Economics and Business}

Vol. 3, No. 3, September-December 2018

ISSN: 2503-4235 (p); 2503-4243 (e)

\section{Table of Contents}

\section{Articles}

Addiarrahman

Ekonomi Kemakmuran Bersama

Indonesian Islamic Economic Thought of KahrudinYunus

Noviy Hasanah

Pasar Resisting Mall

A Cross-Cultural Ethnographic of Economic Traditional Market

Muslich

Implanting Religious Practices

Economic Behavior of Kemloko Tobacco Farmers

Arfah Habib Saragih

Generation XYZ's Perception on Zakat Mal

and Tax A Planned Behavior

Wenda Wahyu Christiyanto, Mardi Astutik

Integrated Marketing and Customers' Decision Saving Funds in Islamic Banks

Sri Walyoto

Carbon Costs of Indonesian Forested Land Conversion to

Oil Palm Plantations 


\title{
Generation XYZ's Perception on Zakat Mal and Tax The Planned Behavior Perspective
}

\author{
Arfah Habib Saragih \\ Department of Fiscal Administration \\ Faculty of Administrative Science Universitas Indonesia \\ arfah.habib11@ui.ac.id
}

\begin{abstract}
The research aims to implement the theory of planned behavior to predict respondent's intention to participate in offering wealth zakat and tax payment. The research used questionnaires, which aims to generate a descriptive research. Technique of analysis being applied is the Partial Least Square (PLS) with SmartPLS software. The final samples used constitute 99 respondents. The descriptive statistics results show that respondents understood that zakat is religious obligation; agreed that paying wealth zakat and tax might help reducing poverty and improving social welfare; more respondents knew that wealth zakat could be used as deducting factor in tax calculation; agreed that they would still pay tax regardless whether the wealth zakat and tax can be a deducting factor for their taxed income or not; respondents paid the wealth zakat directly to mustahik for reasons such as its primacy status, easiness, and proximity/location; other respondents paid their wealth zakat via transfer to the amil zakat institution's account, for its comfort (online payment), professionalism/trustworthiness of the institution. Meanwhile, the analysis results using PLS revealed that attitude, subjective norm, and behavioral control influence one's intention to pay wealth zakat and tax; furthermore, behavioral intention affects actual behavior in paying wealth zakat and tax.
\end{abstract}

Keywords: Zakat, Tax, Theory of Planned Behavior

\section{Introduction}

Poverty and social welfare remain a serious problem that Indonesia faces. To reduce poverty and enhance social welfare, active roles from 
various stakeholders are critical, including government and general public. In Islam, it is expressively mandated that every capable Muslim that meets the threshold shall pay zakat, both zakat fitrah (zakat of the body) and wealth zakat to the mustahik (beneficiary of the zakat). In Surah At-Taubah verse 60, the Qur'an sets forth eight categories of mustahik, namely fakir (needy), miskin (poor), amil zakat (zakat collector), muallaf (convert), slave, debt-bound person, person in jihad, and traveler (musafir). Islam enjoins its followers to help each other reducing poverty and enhance social welfare, including by mandating the zakat for those who meet the requirements.

To distribute the wealth zakat, the zakat donators (muzakki) can pay it directly to the mustahik as well as to the amil zakat institution (lembaga amil zakat/LAZ) Submission of wealth zakat to the LAZ can be performed by directly visit the institution as well as indirectly (by making bank transfer to the LAZ account). The LAZ is the one that distributes the wealth zakat to the mustahik. The mustahiks will receive direct and tangible benefits as it is directly given to them. In Islamic teaching, muzakkis are allowed to offer their wealth zakat directly to the mustahik as well as indirectly through the LAZ. However, Islam encourages that wealth zakat is prioritized for one's closest relatives, before giving it to others. Once there is no more relative that falls into mustahik category, the wealth zakat can be distributed to other people in the community, primarily in the muzakkis neighborhood. However, should there be no more people in the nearby neighborhood that falls into mustahik category, muzakki may bring the zakat to the LAZ which will distribute it to the mustahik in other areas.

In today's world, people are divided by generation, i.e. according to their birth year, namely: traditional generation, baby boomers, X, Y, Z, and Alpha (Wiedmer, 2015). All these generations are currently living in digital era, in which internet-based information technology grows so 
rapidly. The proportion of internet usage by age group is presented on Table 1.

Table. 1 Proportion of Internet Usage by Age Group

\begin{tabular}{ccc}
\hline \multirow{2}{*}{ Age Group } & \multicolumn{2}{c}{$\begin{array}{c}\text { Proportion of Individual Using Internet by Age } \\
\text { Group (in Percent) }\end{array}$} \\
& $\mathbf{2 0 1 5}$ & $\mathbf{2 0 1 6}$ \\
\hline$>15$ & 9.76 & 9.86 \\
$15-24$ & 51.83 & 58.21 \\
$25-64$ & 17.56 & 21.53 \\
$65+$ & 0.83 & 1.18 \\
Total & 79.98 & 90.78 \\
\hline
\end{tabular}

Source: Central Bureau of Statistics (BPS) (2018)

All the aforementioned facilities have made it easier for people to perform their duties, including in paying wealth zakat to mustahik and tax to the government. Nowadays, wealth zakat can not only be given directly to the mustahik, or paid to the nearby amil zakat institution, yet it can also be transferred to the account of various zakat institutions all around the world (via internet banking, mobile banking, etc.). This makes it easier to the muzakkis to pay their zakat to LAZ, which will distribute it to the designated mustahik. The phenomenon should further encourage actual behavior of the Muslims to pay their wealth zakat and tax in order to improve social welfare and contribute to poverty reduction, as it can reach out wider areas. According to the Theory of Planned Behavior (TBP), one's behavior is influenced by his/her intention. Whereas, one's intention is shaped by his/her attitude toward the behavior, subjective norm, and perceived behavioral control through his/her faith/belief.

In addition to paying zakat, Indonesian Muslims are also bound to taxation duties as mandated by the prevailing laws, particularly the income tax which applies for those who have job and satisfy the criteria. According to the Law No. 6 of 1983 regarding General Provisions and Procedure of 
Taxation, which had been substituted by law No. 16 of 2009, tax is defined as a mandatory contribution to the state which is payable by individual or institution that is mandatory in nature in accordance with the law, which does not provide any direct compensation in return and which is used for the state's needs to bring optimum impact for the people. From both types of obligations, a clear difference stands out, i.e. zakat benefit can be felt immediately by the mustahik, while tax benefit cannot. However, both share the same long-term goal, which is creating public prosperity by reducing poverty and increasing social welfare.

Upon observance of such double obligations (wealth zakat and tax), the government passed Law No. 23 of 2011 on Zakat Management, in Article 22 of which sets forth that zakat (zakat fitrahlzakat of body and wealth zakat) paid by muzakki to BAZNAZ or LAZ can deduct taxable income, hence making the tax payable smaller. However, zakat facility as the taxable income (PKP) deductor cannot be used if the muzakki offers the zakat directly to the mustabik. In addition, up to now, not everyone knows that zakat paid to BAZNAZ or LAZ can result in taxable income deduction, despite various available information in numerous media that are practically accessible with their mobile gadget.

Based on the above background, the author found it necessary to conduct a research on inter-generational perception on wealth zakat and tax in digital era to achieve better social welfare by using the Theory of Planned Behavior (TPB). The TPB indicates that one's behavior is influenced by his/her intention, while one's intention is shaped by his/her attitude toward the behavior, subjective norm, and perceived behavioral control through his/her set of belief. The behavior of the three generations (XYZ) becomes important to be raised since the majority of Indonesian population consists of this age group, which is expected to play significant role to create social welfare both through wealth zakat and tax. 
Furthermore, the three generations live in a digital era that eases mobility of information and fund in the cyber-world. Knowledge on obligation to pay zakat for every Muslim is absolutely important, and so is the case with that of paying tax. Such knowledge may influence Muslim citizens of the country to pay zakat and tax as their concrete contribution to reduce poverty, enhance social welfare, and create public prosperity. Discussion on the TPB implementation in this research is expected to provide some critical information on the problems being faced in paying zakat as well as giving recommendation to regulators and zakat institutions.

In Indonesia context, some studies related to compliance in paying zakat and tax have been conducted. Alpriyamah and Adityawarman (2017) found that attitude and subjective norm toward behavioral intention to pay zakat were significant. Moreover, they found that intention to pay zakat was positively significant toward zakat compliance behavior. Lesmana, Panjaitan, and Maimunah (2017) also concluded that in terms of tax compliance, the variables that affecting positively the intention to pay were the control behavioral and moral obligation, while the attitude and subjective norms did not influence it. Yusuf and Ismail (2017) also proved that there was a significant impact of knowledge in taxation and zakat on taxpayers' compliance in paying tax. Saad and Haniffa (2014) found that intention was significant predictor for zakat compliance behavior. Intention was proved to be influenced by attitude and subjective norm.

\section{Theoretical Framework and Hypothesis Development}

Zakat. Zakat constitutes the fourth pillar of Islam. Zakat is divided into two: zakat fitrah (zakat of the body) and wealth zakat. The Qur'an in Surah At-Taubah verse 103 states "take zakat from a part of their wealth to clean and purify them, and supplicate for them. Verily, your prayer will (serve) as a peace of soul for them, and Allah is Most Hearing and Most 
Knowing." The requirements for anyone to be considered as subject to pay zakat are: a Muslim, free (not slave), sane and has reached the age of puberty, and whose asset meets the minimum treshold (nishab). Nishab constitutes the lowest measure or limit set forth by Islam, the exceeding of which makes it mandatory for a person to pay the zakat. Nishab consists of two requirements, namely: a. the wealth is no longer needed for fulfilling one's need, such as food, clothing, housing, vehicle, and tools used for his/her livelihood, and b. the wealth has been in his/her possession for at least one year (has passed the minimum duration of possession/haul). This is in line with the hadits narrated by Tirmidzi, Ibnu Majah, which was proclaimed as hasan (sufficiently legitimate) by Syaikh Al Albani. The payer of zakat (muzakki) shall pay his/her zakat to those entitled to receiving it (mustahik). In Surah At-Taubah verse 60, the Qur'an sets forth eight categories of mustahik, namely fakir (needy), miskin (poor), amil zakat (zakat collector), muallaf (convert), slave, debt-bound person, person in jihad, and musafir (Saad and Haniffa, 2014).

Tax. According to the Law No. 6 of 1983 regarding General Provisions and Procedure of Taxation, which had been substituted by law No. 16 of 2009, tax is defined as a mandatory contribution to the state which is payable by individual or institution that meets the requirements according to the law, which does not provide any direct compensation in return and which is used for the state's needs to bring optimum impact for the people. From both types of obligations, a clear difference stands out, i.e. $z a k a t$ benefit can be felt immediately by the mustahik, while tax benefit cannot. However, both share the same long-term goal, which is creating public prosperity. The current taxable income (PKP) for individual income tax is $5 \%$ for those earning up to IDR $50,000,000 ; 15 \%$ for taxable income above IDR50,000,000 to IDR250,000,000; 25\% for taxable income above IDR250,000,000 to IDR500,000,000; and 30\% for taxable income 
above IDR500,000,000. This tariff indicates that the higher one's taxable income (PKP) is, the higher the amount of tax that should be paid will be.

Zakat as Deductor of Taxable Income (PKP). Due to the double obligations borne by Muslims, the government passed Law Number 23 of 2011 on Zakat Management, the Article 22 of which sets forth that zakat (both zakat fitrah and wealth zakat) paid by muzakki to BAZNAS or LAZ will be a deductor to his/her taxable income. However, direct payment of zakat from muzakki to mustahik cannot be a deductor to taxable income. To observe whether there is impact from zakat as deductor to taxable income, the author provides a simple illustration on Table 2.

Table 2. Illustration of Zakat as Deductor of Taxable Income (PKP).

\begin{tabular}{|c|c|c|c|}
\hline Component & Not Paying Zakat & $\begin{array}{c}\text { Paying Zakat Directly to } \\
\text { Mustabik }\end{array}$ & $\begin{array}{c}\text { Paying Zakat through } \\
\text { BAZNAZ/LAZ }\end{array}$ \\
\hline Gross Income & IDR360,000,000 & IDR360,000,000 & IDR360,000,000 \\
\hline Deduction & IDR6,000,000 & IDR6,000,000 & IDR6,000,000 \\
\hline Zakat & - & $\begin{array}{l}\text { IDR12,000,000 } \\
\text { (however, it cannot be } \\
\text { used as deductor to taxable } \\
\text { income as it does not go } \\
\text { through BAZNAZ/LAZ) }\end{array}$ & IDR $12,000,000$ \\
\hline Net Income & IDR354,000,000 & IDR354,000,000 & Rp342.000.000 \\
\hline Other expense & IDR6,000,000 & IDR6,000,000 & IDR6,000,000 \\
\hline $\begin{array}{l}\text { PTKP (Non- } \\
\text { Taxable } \\
\text { Income) }\end{array}$ & IDR $54,000,000$ & IDR54,000,000 & IDR $54,000,000$ \\
\hline $\begin{array}{l}\text { PKP (Taxable } \\
\text { Income) }\end{array}$ & IDR294,000,000 & IDR294,000,000 & IDR282,000,000 \\
\hline Paid Tax & IDR30,000,000 & IDR30,000,000 & IDR30,000,000 \\
\hline Tax Payable & $\begin{array}{c}\text { Tax Payable } \\
5 \% * 50,000,000 \\
+10 \% * 200,000,000 \\
+25 \% * 104,000,000 \\
=\text { IDR } 48,500,000\end{array}$ & $\begin{array}{c}\text { Tax Payable } \\
5 \% * 50,000,000 \\
+10 \% * 200,000,000 \\
+25 \% * 104,000,000 \\
=\text { IDR } 48,500,000\end{array}$ & $\begin{array}{c}\text { Tax Payable } \\
5 \% * 50,000,000 \\
+10 \% * 200,000,000 \\
+25 \% * 92,000,000 \\
=\text { IDR } 45,500,000\end{array}$ \\
\hline
\end{tabular}




\begin{tabular}{|c|c|c|c|}
\hline $\begin{array}{l}\text { Remaining } \\
\text { Unpaid Tax }\end{array}$ & IDR18,500,000 & IDR18,500,000 & IDR15,500,000 \\
\hline $\begin{array}{l}\text { Total Zakat } \\
\text { and Tax } \\
\text { Obligation }\end{array}$ & $\begin{array}{c}\text { IDR } 48,500,000 \\
(\text { IDR0+IDR48,500,000) }\end{array}$ & $\begin{array}{c}\text { IDR60,500,000 } \\
\text { (IDR12mio+IDR48.5mio) }\end{array}$ & $\begin{array}{c}\text { IDR } 57,500,000 \\
\text { (IDR12mio+IDR45.5mio) }\end{array}$ \\
\hline $\begin{array}{l}\text { Religious } \\
\text { Sanction }\end{array}$ & $\begin{array}{c}\text { Sinful because he/she } \\
\text { is capable but does not } \\
\text { pay zakat }\end{array}$ & $\begin{array}{l}\text { Not sinful since he/she } \\
\text { already paid the } z a k a t\end{array}$ & $\begin{array}{l}\text { Not sinful since he/she } \\
\text { already paid the } z a k a t\end{array}$ \\
\hline
\end{tabular}

Source: Data Processed by Author

The simple illustration shows that the government is serious in its efforts to reduce taxation obligation for the Muslims who pay the zakat through BAZNAZ/LAZ. Zakat obligation is still paid at the amount of IDR12,000,000, yet the tax paid is deducted from IDR48,500,000 to IDR45,500,000, with tax saving amounting IDR3,000,000. Up to now, the zakat that can deduct taxable income is the one officially distributed through BAZNAZ/LAZ which is proven with transfer proof to the zakat institution as well as receipt from it. If the $z a k a t$ is directly distributed to mustahik, muzakki will not get taxable income deduction as he/she won't have any sufficient evidence that can get him/her tax deduction. This causes dillema, because in Islam, it is considered more preferrable (afdhal) if the wealth zakat is paid directly to the eight categories of people who live closest to our neighborhood; only when there is no more of those 8 categories who need it, we can submt the money to the zakat institution that can reach out farther and wider mustahik.

Generational Development. In today's world, people are divided by generation, i.e. according to their birth year, namely: traditional generation, baby boomers, X, Y, Z, and Alpha. All these generations are currently living in digital era, in which internet-based information technology grows so rapidly. This research focuses on generation X, Y, and $\mathrm{Z}$. The behavior of the three generations (XYZ) becomes important to 
be raised since the majority of Indonesian population consists of this age group, which is expected to play significant role to create social welfare both through wealth zakat and tax. Furthermore, the three generations live in a digital era that eases mobility of information and fund in the cyber-world. Knowledge on obligation to pay zakat for every Muslim is absolutely important, and so is the case with that of paying tax. Such knowledge may influence Muslim citizens of the country to pay zakat and tax as their concrete contribution to reduce poverty, enhance social welfare, and create public prosperity.

Generation X is a generation bornt in 1961-1980, while generation $\mathrm{Y}$ was bornt between 1981-1994, while generation $\mathrm{Z}$ is those who were bornt in 1995-2015. When converted, consecutively, the ages between generations in 2018 are as follows: 3-23 years-old for generation Z; 2437 years-old for generation Y; and 38-57 years-old for generation X. Generation $\mathrm{X}$ and $\mathrm{Y}$ are the one dominating the employment today, and thus are expected to meet the threshold of wealth zakat and tax. Swanbrow (2012) in Wiedmer (2015) concluded that Generation X (Post-Boomers) are highly educated, happy, active, balanced, and family oriented. Compared to other generations, Generation Y (Millennials) tend to be less independent, more social and confident, and more inclusively community oriented (Gibson, 2015 in Wiedmer, 2015). While, Generation Z (Digital Natives, iGeneration) are highly connected to the internet, communication, and technology. They tend to be more environmentally and socially aware than previous generations $\mathrm{X}$ and $\mathrm{Y}$.

Theory of Planned Behavior (TPB). The theory was developed by Ajzen (1980, 1985, and 1991). According to this theory, one's behavior is influenced by his/her intention. Whereas, one's intention is shaped by his/her attitude toward the behavior, subjective norm, and perceived behavioral control through his/her faith/belief. Attitude toward the 
behavior. Attitude is the product of a sensitization process, in which a person reacts in accordance with the stimulation he/she receives. Attitude is a form of feeling evaluation. One's attitude to an object is a supportive or favorable feeling and non-supportive or unfavorable feeling toward the object. Attitude plays a critical role in explaining one's behavior in his/ her environment, although there are many more factors influencing it, such as stimulus, individual's background, motivation, and personality. Reciprocally, environmental factor also influences attitude and behavior. Ajzen (2002) said the attitude toward the behavior is determined by the behavioral beliefs of an individual.

Subjective norm. Subjective norm refers to an individual's perception on the social influence in forming certain behavior (Ajzen, 1980, 1985). Subjective norm is a function of hope that is perceived by an individual, in which one of more persons around the individual (such as relative, peer) agree on certain behavior and motivate the individual to obey them (Ajzen, 1991). Ajzen (2002) suggested that subjective norm is determined by normative beliefs of an individual that causes social pressure or subjective norm.

Perceived behavioral control. Behavioral control that is perceived in this context reflects how strong a control of a taxpayer is in showing a certain behavior, such as reporting his/her income to be lower than the real one, improperly deduct his/her income, as well as other incompliant behaviors. This means, the stronger one's level of control is, the more hel she can influence the compliance behavior. Ajzen (2002) argued that behavioral control that is perceived gives motivational implication to the individual that will perform such behavior. This means, intention will be formed when the individual feels capable of showing a particular behavior.

Behavioral intention. Behavioral intention is an intermediary variable in shaping behavior (Ajzen 2002). In the Theory of Planned 
Behavior (TPB), a behavior performed by an individual emerges due to his/her individual to perform the behavior. Meanwhile, the occurrence of behavioral intention is determined by 3 key factors, namely behavioral beliefs, normative beliefs, and control beliefs. Generally, human acts in accordance with his/her intention/tendency. Actual behavior. Actual behavior is the real behavior materialized from the previously formed behavioral intention. It is this actual behavior that is key to determine whether the behavioral intention to pay wealth zakat and tax is truly implemented or not to reduce poverty and increase social welfare.

The Theory of Planned Behavior (TPB) is a theory that has been frequently tested in various behavioral researches around the world. According to this theory, one's behavior is influenced by his/her intention. Whereas, one's intention is shaped by his/her attitude toward the behavior, subjective norm, and perceived behavioral control through his/her faith/ belief. Thus, the hypotheses of this research are as follows:

a. H1: Respondent's attitude influences his/her compliant behavioral intention to pay wealth zakat and tax

b. H2: Respondent's subjective norms influences the compliant behavioral intention to pay wealth zakat and tax

c. H3: Behavioral control felt by respondent influences one's behavioral intention to pay wealth zakat and tax

d. H4: Respondent's intention influences his/her compliant behavior to pay wealth zakat and tax

\section{Research Method}

Research Population and Sample. The initial sample of this research consisted of 133 respondents filling out online questionnaire by using google-form. Data sampe collection was conducted randomly in July 2018. Due to screening process conducted (to those who had paid wealth 
zakat and had taxpayer number/NPWP), the final samples of this research were 99 respondents. The use of this number of respondents has been met the minimum criteria in conducting the research which is 30 respondents (Sekaran, 2003).

Flowchart Diagram and Research Model. The flowchart diagram and research model use the following Theory of Planned Behavior (TPB). Notes that the description for all items are as follows: $S=$ Sikap = Attitude; NS = Norma Subjektif $=$ Subjective Norms; KP = Kontrol Perilaku Persepsian $=$ Perceived Behavioral Control; $\mathrm{MP}=$ Minat Perilaku $=$ Behavioral Intention; and PA = Perilaku Aktual = Actual Behavior

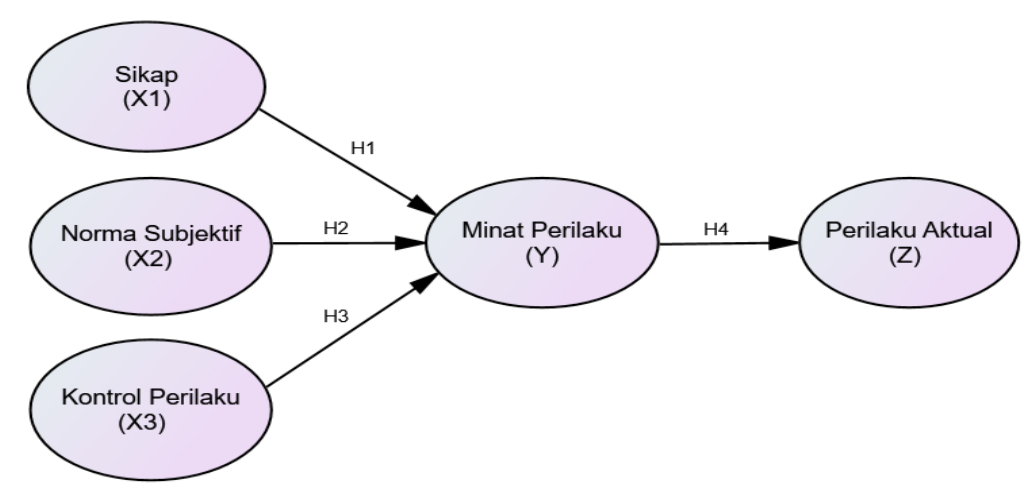

Figure 1. Flowchart Diagram of the Research Source: Processed with SmartPLS 


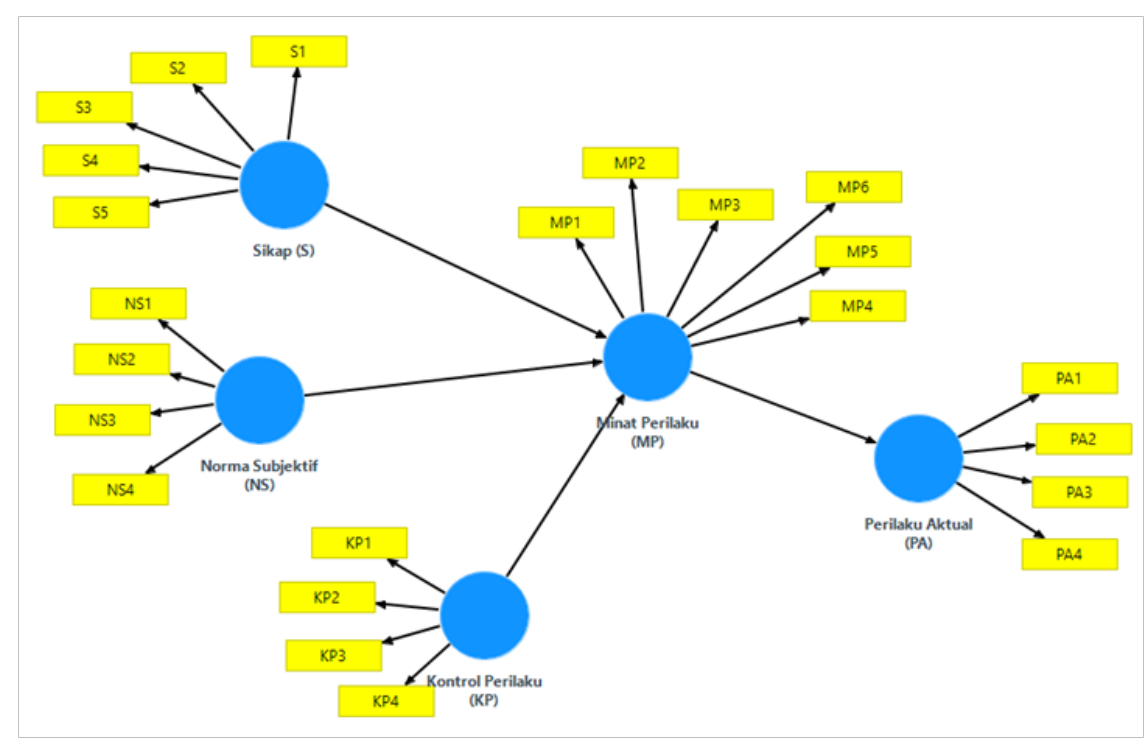

Figure 2. Research Model

\section{Source: Processed with SmartPLS}

Data Processing Technique. The data processing techniques in this research consist of descriptive statistic and Structural Equation Model (SEM), in form of Partial Least Square (PLS) which is assisted by SmartPLS software. SEM is an analysis method that is frequently used to describe model that comprises relations between various variables. One of the advantages of SEM is its ability to analyze relationship pattern directly between latent variable and indicators, latent with latent, as well as calculate level of error in measurement. The level of trust used in this research is $95 \%$. The steps in using PLS are as follows:

1. Evaluation of measurement model (outer model), Convergent Validity, Discriminant Validity, Composite Reliability

2. Evaluation of structural model (inner model), R-Square Test, Q-Square Test

3. Designing flowchart diagram, drawing a Full Structural Model

4. Developing a model equation system (equation table and model) 


\section{Result}

Descriptive Statistics. Final respondents in this research consisted of 99 people, with demographic data as follows: The composition is dominated by Generation Y (50\% of the sample) and more female than male (Table 3). Table 4 also shows that the majority of respondents are from bachelor-degree background, followed by master-degree and diploma-degree.

\section{Tabel 3. Respondents' Data}

\begin{tabular}{|c|c|c|c|c|c|}
\hline Generation & Age & Male & Female & Total & Percentage \\
\hline $\mathrm{X}$ & $38-57$ & 24 & 18 & 42 & $42.42 \%$ \\
\hline Y & $24-37$ & 18 & 32 & 50 & $50.50 \%$ \\
\hline Z & $\leq 23$ & 4 & 3 & 7 & $7.08 \%$ \\
\hline \multicolumn{4}{|c|}{ Total } & 99 & $100 \%$ \\
\hline
\end{tabular}

Source: Data Processed by Author

\section{Tabel 4. Respondents' Degree Background}

\begin{tabular}{ccccccc}
\hline Generation & Age & $\begin{array}{c}\text { Senior High } \\
\text { School }\end{array}$ & Diploma & Bachelor & Master & Doctor \\
\hline $\mathrm{X}$ & $38-57$ & 0 & 4 & 17 & 19 & 2 \\
$\mathrm{Y}$ & $24-37$ & 0 & 9 & 35 & 5 & 1 \\
$\mathrm{Z}$ & $\leq 23$ & 1 & 3 & 2 & 1 & 0 \\
\multicolumn{2}{c}{ Total } & 1 & 16 & 54 & 25 & 3 \\
\multicolumn{2}{c}{ Percentage } & $1.01 \%$ & $16.16 \%$ & $54.55 \%$ & $25.25 \%$ & $3.03 \%$ \\
\hline
\end{tabular}

Source: Data Processed by Author

Table 5 shows respondents' way to distribute their wealth zakat, and out of the 99 respondents, 51 paid their zakat directly to mustahik, 44 transferred to LAZ, and 4 answered others (took the money directly to LAZ or mosque). The fact that this generation lives in digital era doesn't 
necessarily change their pattern of paying wealth zakat. This is shown from their behavioral pattern that still prefer to pay the zakat directly to mustahik, followed with transfer to LAZ.

Table 5. Way to Distribute Their Wealth Zakat

\begin{tabular}{ccrrrr}
\hline Gen & Age & $\begin{array}{l}\text { Direct to } \\
\text { Mustahik }\end{array}$ & $\begin{array}{c}\text { Transfer } \\
\text { to LAZ }\end{array}$ & Other & \multicolumn{1}{c}{ Total } \\
\hline $\mathrm{X}$ & $38-57$ & 21 & 20 & 1 & 42 \\
$\mathrm{Y}$ & $24-37$ & 27 & 21 & 2 & 50 \\
$\mathrm{Z}$ & $\leq 23$ & 3 & 3 & 1 & 7 \\
\multicolumn{2}{c}{ Total } & 51 & 44 & 4 & 99 \\
\hline
\end{tabular}

Source: Data Processed by Author

Respondents said that they prefer to pay the wealth zakat directly to mustahik due to the following reasons:

1. It's more preferrable (afdhal) since it complies more with the Qur'an and hadits that encourage prioritizing closest relatives, and meet directly with the mustahik,

2. Cheaper, practical, directed, and effective, because it is given directly to the mustahik who needs it, as well as as a means to develop their own neighborhood,

3. It's more useful for the mustahik domiciling close to him/her,

4. Already knows the mustahik's real condition well,

5. Many mustahiks in the need, but not reached out yet by zakat institution.

Meanwhile, respondents who prefer to pay the wealth zakat through transfer to zakat institution account suggested the following reasons:

1. Easier, practical, flexible, and simple, since it is directly transferred to the zakat institution, 
2. Zakat institution is considered more credible/trustworthy, and thus they trust the zakat institution to act as the amil zakat (zakat collector),

3. It is more well-organized and can reach out wider mustabiks,

4. Busy working, hence prefer to entrust the distribution to a professional zakat institution,

5. Make use of the existing internet and mobile banking facilities.

Respondents who answered with other means stated the following reasons:

1. Directly take the money to the mosque and zakat institution since it is easier and the location is close,

2. Already trust the zakat institution.

Table 6 shows the descriptive statistics results for some significant indicators. In accordance with the descriptive analysis on the respondents' answers in this research, it was also found out that $98 \%$ of respondents agreed to pay the wealth zakat as mandated by the religion, and $75 \%$ agreed to pay tax according to the law. In addition, $83 \%$ of respondents agreed that wealth zakat and tax that they paid could increase social welfare, and $78 \%$ of respondents agreed that wealth zakat and tax that they paid might reduce poverty. 


\section{Table 6. Descriptive Statistics for Some Significant Indicators}

\begin{tabular}{|c|c|c|c|c|c|c|c|c|}
\hline Indicator & Gen & $\begin{array}{l}\text { Strongly } \\
\text { Disagree }\end{array}$ & Disagree & $\begin{array}{c}\text { Rather } \\
\text { Disagree }\end{array}$ & $\begin{array}{c}\text { Rather } \\
\text { Agree }\end{array}$ & Agree & $\begin{array}{c}\text { Strongly } \\
\text { Agree }\end{array}$ & Total \\
\hline \multirow{3}{*}{$\begin{array}{l}\text { I want to pay my } \\
\text { wealth zakat in } \\
\text { accordance with } \\
\text { the religion }\end{array}$} & $\mathrm{X}$ & 0 & 1 & 0 & 1 & 1 & 39 & 42 \\
\hline & $\mathrm{Y}$ & 0 & 0 & 0 & 0 & 4 & 46 & 50 \\
\hline & Z & 0 & 0 & 0 & 0 & 0 & 7 & 7 \\
\hline Total & & 0 & 1 & 0 & 1 & 5 & 92 & 99 \\
\hline Percentage & & $0 \%$ & $1 \%$ & $0 \%$ & $1 \%$ & $5 \%$ & $93 \%$ & $100 \%$ \\
\hline \multirow{3}{*}{$\begin{array}{c}\text { I want to pay my } \\
\text { tax in accordance } \\
\text { with the taxation } \\
\text { law }\end{array}$} & $\mathrm{X}$ & 1 & 1 & 7 & 2 & 9 & 22 & 42 \\
\hline & $\mathrm{Y}$ & 2 & 2 & 3 & 6 & 9 & 28 & 50 \\
\hline & Z & 0 & 1 & 0 & 0 & 2 & 4 & 7 \\
\hline Total & & 3 & 4 & 10 & 8 & 20 & 54 & 99 \\
\hline Percentage & & $3 \%$ & $4 \%$ & $10 \%$ & $8 \%$ & $20 \%$ & $55 \%$ & $100 \%$ \\
\hline \multirow{3}{*}{$\begin{array}{l}\text { I feel that the } \\
\text { wealth zakat and } \\
\text { tax I pay can } \\
\text { improve social } \\
\text { welfare }\end{array}$} & $\mathrm{X}$ & 0 & 2 & 2 & 7 & 5 & 26 & 42 \\
\hline & $\mathrm{Y}$ & 0 & 0 & 3 & 3 & 7 & 37 & 50 \\
\hline & Z & 0 & 0 & 0 & 0 & 1 & 6 & 7 \\
\hline Total & & 0 & 2 & 5 & 10 & 13 & 69 & 99 \\
\hline Percentage & & $0 \%$ & $2 \%$ & $5 \%$ & $10 \%$ & $13 \%$ & $70 \%$ & $100 \%$ \\
\hline \multirow{3}{*}{$\begin{array}{l}\text { I feel that the } \\
\text { wealth zakat and } \\
\text { tax I pay can } \\
\text { reduce poverty }\end{array}$} & $\mathrm{X}$ & 0 & 2 & 2 & 8 & 6 & 24 & 42 \\
\hline & $\mathrm{Y}$ & 0 & 0 & 5 & 4 & 6 & 35 & 50 \\
\hline & $\mathrm{Z}$ & 0 & 0 & 0 & 1 & 0 & 6 & 7 \\
\hline Total & & 0 & 2 & 7 & 13 & 12 & 65 & 99 \\
\hline Percentage & & $0 \%$ & $2 \%$ & $7 \%$ & $13 \%$ & $12 \%$ & $66 \%$ & $100 \%$ \\
\hline \multirow{3}{*}{$\begin{array}{l}\text { I know that wealth } \\
\text { zakat can be used } \\
\text { as a tax deductor }\end{array}$} & $\mathrm{X}$ & 2 & 1 & 2 & 6 & 6 & 25 & 42 \\
\hline & Y & 8 & 2 & 5 & 6 & 5 & 24 & 50 \\
\hline & Z & 0 & 0 & 0 & 0 & 2 & 5 & 7 \\
\hline Total & & 10 & 3 & 7 & 12 & 13 & 54 & 99 \\
\hline Percentage & & $10 \%$ & $3 \%$ & $7 \%$ & $12 \%$ & $13 \%$ & $55 \%$ & $100 \%$ \\
\hline \multirow{3}{*}{$\begin{array}{l}\text { I will still pay my } \\
\text { tax with or without } \\
\text { wealth zakat as tax } \\
\text { deductor }\end{array}$} & $\mathrm{X}$ & 1 & 3 & 4 & 3 & 7 & 24 & 42 \\
\hline & $\mathrm{Y}$ & 3 & 0 & 3 & 8 & 9 & 27 & 50 \\
\hline & Z & 0 & 0 & 1 & 0 & 1 & 5 & 7 \\
\hline Total & & 4 & 3 & 8 & 11 & 17 & 56 & 99 \\
\hline Percentage & & $4 \%$ & $3 \%$ & $8 \%$ & $11 \%$ & $17 \%$ & $57 \%$ & $100 \%$ \\
\hline
\end{tabular}

Sources: Processed by Author

From the data on Table 6, overall, it can be described that respondents understood that zakat is a religious obligation; respondents also agreed that paying wealth zakat and tax might help reducing poverty and improving social welfare; more respondents knew that wealth zakat could be used as deducting factor in tax calculation; more respondents 
agreed that they would still pay tax regardless whether the wealth zakat and tax can be a deducting factor for their taxed income or not; respondents paid the wealth zakat directly to the mustahik (beneficiary) for reasons such as its primacy status, easiness, and proximity/location; other respondents paid their wealth zakat via transfer to the amil zakat institution's account, for its comfort (with online payment), professionalism and trustworthiness of the institution. Meanwhile, the analysis results using Partial Least Square revealed that attitude, subjective norm, and perceived behavioral control influence one's intention to pay wealth zakat and tax; furthermore, behavioral intention affects actual behavior in paying wealth zakat and tax.

Partial Least Square. Interpretation of outer model result. The calculation result of the Partial Least Square (PLS) Algorithm (outer model) of the valuation of outer model measurement/Partial Least Square (PLS) aims to identify the validity and reliability of the indicators measuring latent variables.

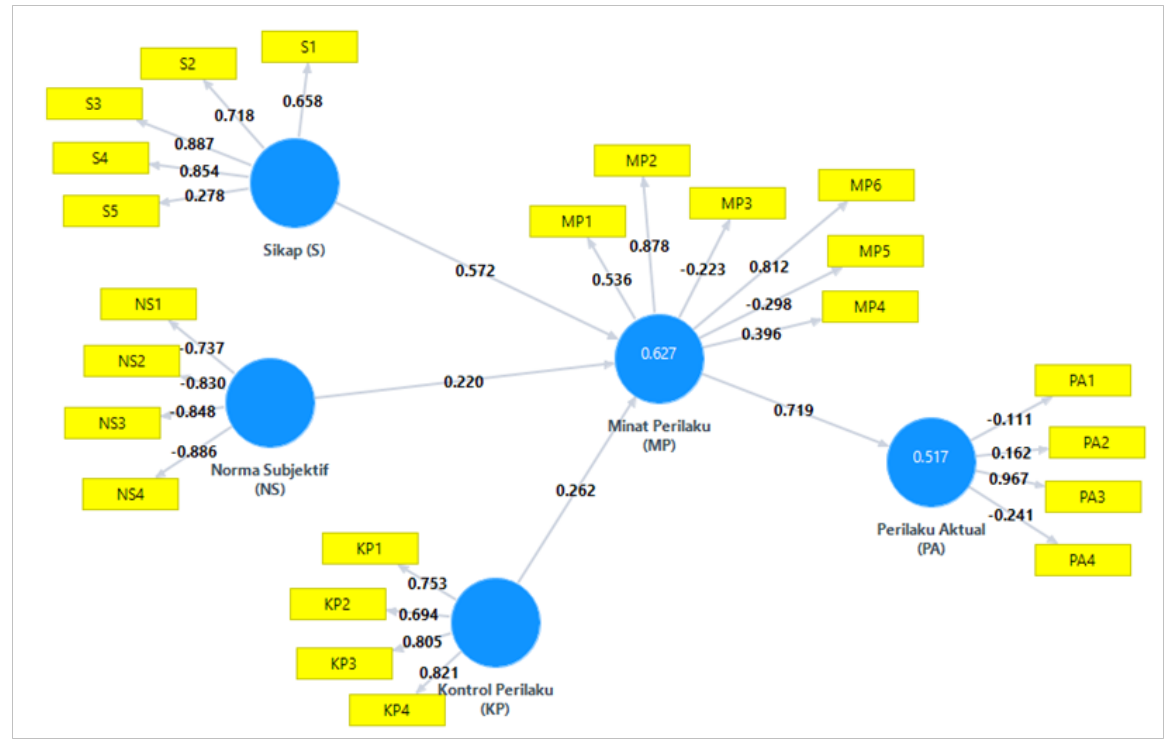

Figure 3. Diagram of the First Stage

Source: Processed by using SmartPLS

Vol. 3 No. 3, September - December 2018 
The validity testing criteria in a research refers to the size of outer loading of each indicator toward its latent variable. It is shown in the following diagram on the first stage research model and outer loading output.

Table 7. Outer Loadings of the First Stage

\begin{tabular}{|c|c|c|c|c|c|}
\hline & $\begin{array}{c}\text { Perceived } \\
\text { Behavioral } \\
\text { Control (PBC) }\end{array}$ & $\begin{array}{l}\text { Behavioral } \\
\text { Intention } \\
\text { (BI) }\end{array}$ & $\begin{array}{c}\text { Subjective } \\
\text { Norms (SN) }\end{array}$ & $\begin{array}{l}\text { Actual } \\
\text { Behavior } \\
\text { (AB) }\end{array}$ & $\begin{array}{l}\text { Attitude } \\
\text { (A) }\end{array}$ \\
\hline PBC1 & 0.753 & & & & \\
\hline PBC2 & 0.694 & & & & \\
\hline PBC3 & 0.805 & & & & \\
\hline PBC4 & 0.821 & & & & \\
\hline BI1 & & 0.536 & & & \\
\hline BI2 & & 0.878 & & & \\
\hline $\mathrm{BI} 3$ & & -0.223 & & & \\
\hline BI4 & & 0.396 & & & \\
\hline BI5 & & -0.298 & & & \\
\hline BI6 & & 0.812 & & & \\
\hline SN1 & & & -0.737 & & \\
\hline SN2 & & & -0.830 & & \\
\hline SN3 & & & -0.848 & & \\
\hline SN4 & & & -0.886 & & \\
\hline $\mathrm{AB} 1$ & & & & -0.111 & \\
\hline $\mathrm{AB} 2$ & & & & 0.162 & \\
\hline AB3 & & & & 0.967 & \\
\hline $\mathrm{AB} 4$ & & & & -0.241 & \\
\hline A1 & & & & & 0.658 \\
\hline A2 & & & & & 0.718 \\
\hline A3 & & & & & 0.887 \\
\hline A4 & & & & & 0.854 \\
\hline A5 & & & & & 0.278 \\
\hline
\end{tabular}

Source: Processed by using SmartPLS

Vol. 3 No. 3, September - December 2018 
Analysis of Convergent Validity. Convergent Validity is the measurement of reflective indicator validity as a variable measurer which can be seen from the outer loading of each variable indicator. An indicator's reliability is considered good when its outer loading value is above 0.70 (Jonathan Sarwono, 2014). Meanwhile, outer loading value can still be tolerated until 0.50 , while that below 0.50 can be dropped from the analysis (Ghozali, 2015). In accordance with the research diagram Stage_1 and above output of the Outer Loading it can be seen that there are indicators which have loading factor value below 0.5 (95\%), which are MP3 (-0.223), MP4 (0.396), MP5 (-0,298), PA1 (-0,111), PA2 (0.162), PA4 (-0,241), and S5 (0.278). Indicators which loading factors are below 0.5 are dropped from the subsequent research. The result is the second stage (Stage_2) Research Diagram with Outer Loading out as follows.

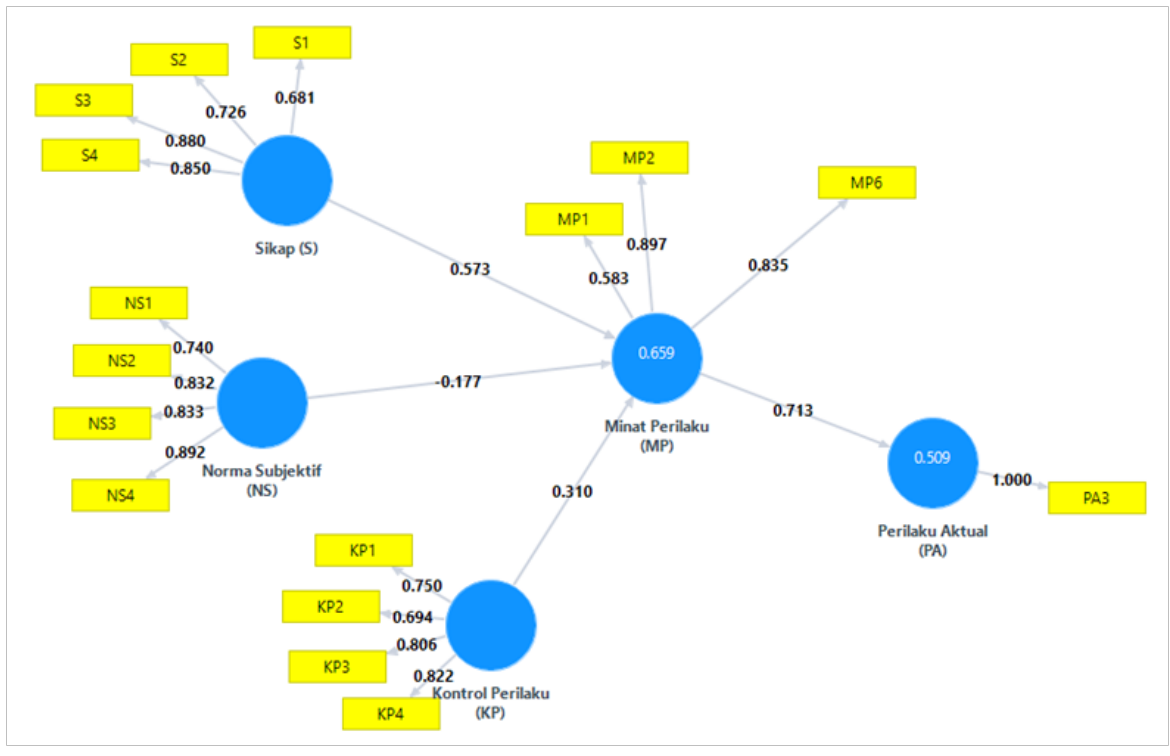

Figure 4. Diagram of the Second Stage

Source: Processed by using SmartPLS 
Tabel 8. Outer Loadings of the Second Stage

\begin{tabular}{|c|c|c|c|c|c|}
\hline & $\begin{array}{c}\text { Perceived } \\
\text { Behavioral } \\
\text { Control (PBC) }\end{array}$ & $\begin{array}{l}\text { Behavioral } \\
\text { Intention } \\
\text { (BI) }\end{array}$ & $\begin{array}{l}\text { Subjective } \\
\text { Norms } \\
\text { (SN) }\end{array}$ & $\begin{array}{l}\text { Actual } \\
\text { Behavior } \\
\text { (AB) }\end{array}$ & $\begin{array}{l}\text { Attitude } \\
\text { (A) }\end{array}$ \\
\hline PBC1 & 0.750 & & & & \\
\hline PBC2 & 0.694 & & & & \\
\hline РBC3 & 0.806 & & & & \\
\hline PBC4 & 0.822 & & & & \\
\hline BI1 & & 0.583 & & & \\
\hline BI2 & & 0.897 & & & \\
\hline BI6 & & 0.835 & & & \\
\hline SN1 & & & 0.740 & & \\
\hline SN2 & & & 0.832 & & \\
\hline SN3 & & & 0.833 & & \\
\hline SN4 & & & 0.892 & & \\
\hline AB3 & & & & 1.000 & \\
\hline $\mathrm{A} 1$ & & & & & 0.681 \\
\hline A2 & & & & & 0.726 \\
\hline A3 & & & & & 0.880 \\
\hline A4 & & & & & 0.850 \\
\hline
\end{tabular}

Source: Processed by using SmartPLS

Analysis of Discriminant Validity. The first criteria to measure discriminant validity of reflective indicator can be seen from the crossloading between indicators and their construct. The table shows that the construct correlation between behavior control with its indicator is higher than the correlation of other construct indicators. This applies vice versa. This indicates that the latent construct predicts indicator in their block better than the other block indicators. 
Table 9. Discriminant Validity

\begin{tabular}{|c|c|c|c|c|c|}
\hline & $\begin{array}{c}\text { Perceived } \\
\text { Behavioral } \\
\text { Control (PBC) } \\
\end{array}$ & $\begin{array}{c}\text { Behavioral } \\
\text { Intention (BI) }\end{array}$ & $\begin{array}{l}\text { Subjective } \\
\text { Norms (SN) }\end{array}$ & $\begin{array}{c}\text { Actual } \\
\text { Behavior (AB) }\end{array}$ & $\begin{array}{l}\text { Attitude } \\
\text { (A) }\end{array}$ \\
\hline PBC1 & $\ulcorner 0.750$ & 0.458 & 0.065 & 0.196 & 0.408 \\
\hline $\mathrm{PBC} 2$ & 0.694 & 0.338 & 0.037 & 0.243 & 0.331 \\
\hline PBC3 & 0.806 & 0.478 & -0.105 & 0.317 & 0.414 \\
\hline PBC4 & 0.822 & 0.558 & -0.137 & 0.451 & 0.389 \\
\hline BI1 & 0.410 & $\Gamma 0.583$ & -0.015 & 0.315 & 0.605 \\
\hline BI2 & 0.534 & 0.897 & -0.251 & 0.722 & 0.699 \\
\hline BI6 & 0.477 & L 0.835 & -0.284 & 0.571 & 0.444 \\
\hline SN1 & -0.122 & -0.120 & -0.740 & -0.160 & -0.013 \\
\hline SN2 & -0.099 & -0.164 & 0.832 & -0.187 & -0.030 \\
\hline $\mathrm{SN} 3$ & 0.022 & -0.144 & 0.833 & -0.143 & -0.034 \\
\hline SN4 & -0.028 & -0.306 & 0.892 & -0.320 & -0.161 \\
\hline AB3 & 0.404 & 0.713 & -0.272 & 1.000 & -0.537 \\
\hline A1 & 0.479 & 0.625 & 0.013 & 0.440 & {$[0.681$} \\
\hline A2 & 0.377 & 0.563 & -0.039 & 0.435 & 0.726 \\
\hline A3 & 0.377 & 0.603 & -0.155 & 0.415 & 0.880 \\
\hline A4 & 0.325 & 0.532 & -0.134 & 0.386 & L 0.850 \\
\hline
\end{tabular}

Source: Processed by using SmartPLS

Construct Reliability Test. Data reliability test (reliability test) is performed to measure consistency and stability of scores (measurement scale) from an instrument in measuring a certain concept and support the goodness value of a measurement instrument. Data quality test is performed by observing the composite reliability value produced from PLS calculation of the existing variables, namely: Attitude (S), Subjective Norm (NS), Behavioral Control (KP), Behavioral Intention (MP), and Actual Behavior (PA). To determine composite reliability, when the composite reliability value is $\mathrm{pc}>0.8$, it can be said that the construct has high reliability or reliable, while pc $>0.6$ is considered fairly reliable (Ghozali, 2011), and Average Variance Extracted (AVE) $>0.50$. 
Table 10. Average Variance Extracted, Composite Reliability, and Cronbachs Alpha

\begin{tabular}{cccc}
\hline Description & $\begin{array}{c}\text { Average Variance } \\
\text { Extracted (AVE) }\end{array}$ & $\begin{array}{c}\text { Composite } \\
\text { Reliability (CR) }\end{array}$ & $\begin{array}{c}\text { Cronbachs } \\
\text { Alpha }\end{array}$ \\
\hline Attitude & 0.621 & 0.867 & 0.791 \\
Subjective Norms & 0.682 & 0.895 & 0.855 \\
Perceived Behavioral & 0.593 & 0.853 & 0.773 \\
Control & 0.614 & 0.822 & 0.671 \\
Behavioral Intention & 1.000 & 1.000 & 1.000 \\
\hline Actual Behavior & &
\end{tabular}

Source: Processed by using SmartPLS

The reliability test result in the above shows that all research variables have good reliability level. This is visible from the Outer Model, as well as the composite reliability value of the cronbach alpha value, composite reliability result such as in the above Figure. Composite reliability for each construct is very good as they value above 0.80 . In addition, it can also be seen from the cronbach alphavalue which is above 0.70 . The validity of each construct is tested by using Average Variance Extracted (AVE) construct with good validity as it values more than 0.50 (Ghozali, 2015).

\section{Discussion}

Interpretation of Inner Model Result. The result of Calculate Partial Least Square (PLS) Bootsrapping (Inner Model). The inner model testing or structural model is conducted to identify the relation between variables, as well as the significance and $\mathrm{R}$-square values of the research model. Hypothesis test is based upon values found in the structural model analysis, while the level of path coefficient significance is obtained from the $t$-value and the standardized path coefficient value. 


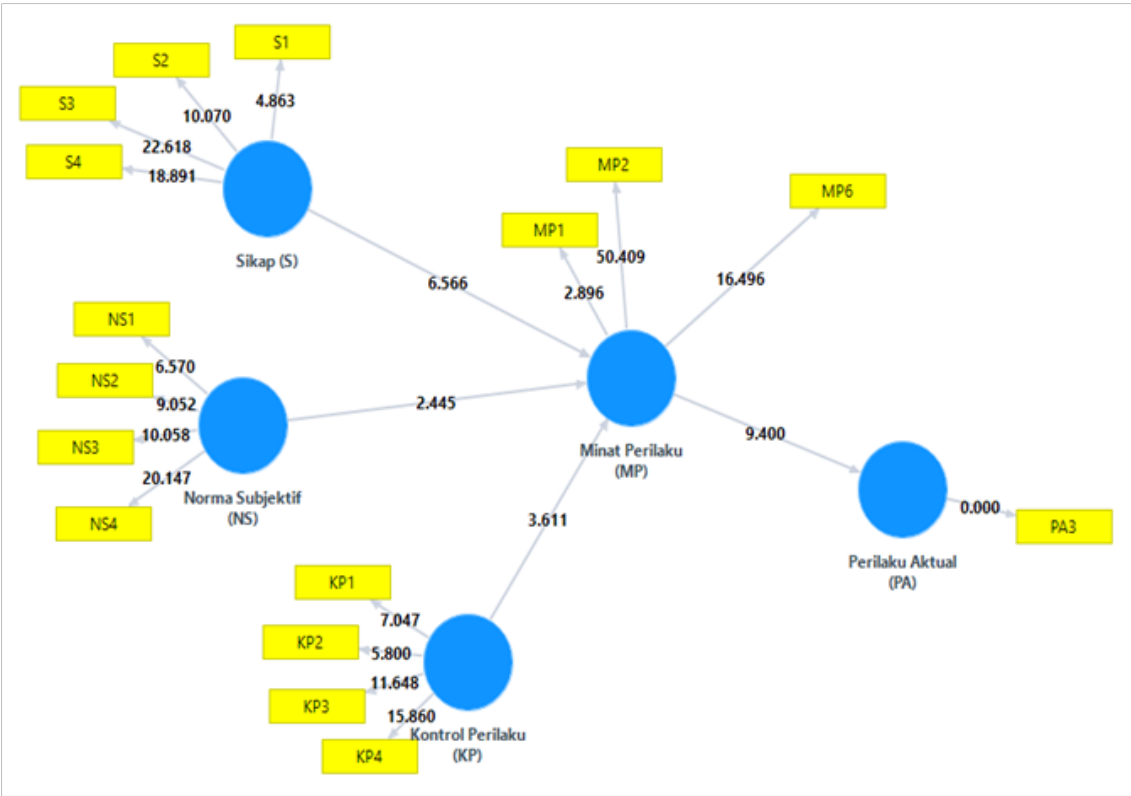

Figure 5. Final Diagram for Further Analysis

Source: Processed by using SmartPLS

Table 11. Path Coefficients

\begin{tabular}{cccccc}
\hline & $\begin{array}{c}\text { Original } \\
\text { Sample (O) }\end{array}$ & $\begin{array}{c}\text { Sample } \\
\text { Mean (M) }\end{array}$ & $\begin{array}{c}\text { Standard Error } \\
(\text { STERR) }\end{array}$ & $\begin{array}{c}\text { T Statistics } \\
(\mid \mathbf{O} \text { /STERR|) }\end{array}$ & $\begin{array}{c}\text { P } \\
\text { Values }\end{array}$ \\
\hline $\mathrm{PBC} \rightarrow \mathrm{BI}$ & 0.310 & 0.319 & 0.086 & 3.586 & 0.000 \\
$\mathrm{BI} \rightarrow \mathrm{AB}$ & 0.713 & 0.712 & 0.082 & 8.693 & 0.000 \\
$\mathrm{SN} \rightarrow \mathrm{BI}$ & -0.177 & -0.193 & 0.071 & 2.507 & 0.012 \\
$\mathrm{~A} \rightarrow \mathrm{BI}$ & 0.573 & 0.546 & 0.087 & 6.602 & 0.000 \\
\hline
\end{tabular}

Source: Processed by using SmartPLS

The limit of hypothesis test value is when its factor loadings t-value is higher than the critical value ( $\geq 1.96$ ). Inner model or structural model test is performed on the research diagram or model at Stage_ 2 in the above, which has dropped any indicators that have loading factor below 0.5 . It is then run by using calculate $\rightarrow$ bootsrapping on PLS. Model Equation: 
Actual Behavior $=0,713^{*}$ Behavioral Intention $+0,573^{*}$ Attitude 0,177*Subjective Norm + $0.310 *$ Behavioral Control + Error

The structural model can be evaluated by using $\mathrm{R}$-square for dependent variable. The above table shows the R-square value of Behavioral Intention variable at 0.659 , which means that the Behavioral Intention variable that can be explained by variables of Attitude, Subjective Norm, and Behavioral Control are 65.9\%. The same case applies with R-square of Actual Behavior variable, which is at 0.509 , which means that the Actual Behavior variable that can be explained by the variables of Attitude, Subjective Norm, Behavioral Control and Behavioral Intention are 50.9\%. The higher the R-square variable is, the higher the independent variable's ability to explain the dependent variable, making the structural equation better.

Table 12. R-Square

\begin{tabular}{lr}
\hline & R-square \\
\hline Behavioral Intention (BI) & 0.659 \\
\hline Actual Behaviour (AB) & 0.509 \\
\hline
\end{tabular}

Source: Processed by using SmartPLS

Based on the above structural model test result, it can be concluded that: First hypothesis: there is influence from Attitude toward Behavioral Intention, and the result of statistic t-value is $6.602 \geq 1.96$ (look Table in the above), so that it can be concluded that there are positive influences to Respondents' behavior to the behavioral intention of compliantly paying wealth zakat and tax. Respondents' attitude i.e. their understanding that wealth zakat is an obligation mandated by religion, paying tax is an obligation toward the law, and feeling that the wealth zakat and tax paid can improve social welfare and reduce proverty have encouraged them to have intention to pay the wealth zakat and tax. In accordance with the 
descriptive analysis on the respondents' answers in this research, it was also found out that $98 \%$ of respondents agreed to pay the wealth zakat as mandated by the religion, and $75 \%$ agreed to pay tax according to the law. In addition, $83 \%$ of respondents agreed that wealth $z a k a t$ and tax that they paid could increase social welfare, and $78 \%$ of respondents agreed that wealth zakat and tax that they paid might reduce poverty.

The second hypothesis: there is influence of Subjective Norms to the Behavioral Intention, and the statistic t-value result is 2,507 $\geq 1.96$ (see the above Table), hence it can be concluded that there are negative influences of the respondents' negative norms, which affect their compliance in paying the wealth zakat and tax. Subjective norms is being reflected by respondents' decision to pay wealth zakat and tax due to their family/friend's influence, paying wealth zakat and tax due to zakat officer and tax officer's influence, all of which bring negative influence to their intention to pay tax. This can be interpreted that respondents intend to pay the zakat not because of their family/friend, or zakat officer's influence, but rather, because they seek rewards from Allah.

The third hypothesis: there is influence from Behavioral Control to Behavioral Intention, with the statistic t-value result of $3.586 \geq 1.96$ (see the above table), hence it can be concluded that there is positive influence from Behavioral Control felt by respondents toward their behavioral intention to pay wealth zakat and tax. Behavioral control in form of guilty feeling and feeling sinful if they don't pay wealth zakat will push respondents to pay their wealth zakat. So is the case with behavioral control, which refers to the possibility of respondents being investigated by tax officer and subjected to sanction if they don't pay the tax. This situation generates respondents' intention to pay tax to the government.

The fourth hypothesis: There is influence from Behavioral Intention to Actual Behavior, with statistic t-value result of $8.693 \geq 1.96$ 
(see the above table), and hence it can be concluded that there is positive influence from respondents' intention toward their compliance in paying their wealth zakat and tax. This shows that the intention that the already formed intention influences positively their compliance in paying wealth zakat and tax, as well as respondents' behavior who will pay the tax, whether it would lead to deduction of their taxable income or not.

Overall, this result supports the previous studies executed by Alpriyamah and Adityawarman (2017) that found the attitude and subjective norm toward behavioral intention to pay zakat were significant; Lesmana, Panjaitan, and Maimunah (2017) that concluded in terms of tax compliance, the variables that affecting positively the intention to pay were the control behavioral; Saad and Haniffa (2014) that found intention was significant predictor for zakat compliance behavior, intention was proved to be influenced by attitude and subjective norm.

The descriptive statistics results show that respondents understood that zakat is a religious obligation; respondents also agreed that paying wealth zakat and tax might help reducing poverty and improving social welfare; more respondents knew that wealth zakat could be used as deducting factor in tax calculation; more respondents agreed that they would still pay tax regardless whether the wealth zakat and tax can be a deducting factor for their taxed income or not; respondents paid the wealth zakat directly to the mustahik (beneficiary) for reasons such as its primacy status, easiness, and proximity/location; other respondents paid their wealth zakat via transfer to the amil zakat institution's account, for its comfort (with online payment), professionalism and trustworthiness of the institution. Meanwhile, the analysis results using Partial Least Square revealed that attitude, subjective norm, and perceived behavioral control influence one's intention to pay wealth zakat and tax; furthermore, behavioral intention affects actual behavior in paying wealth zakat and tax. 
In making decision, both amil zakat institution and regulator can adopt the Theory of Planned Behavior which covers attitude, subjective norm, and perceived behavioral control, which proved to influence one's intention to pay wealth zakat and tax; furthermore, behavioral intention affects actual behavior in paying wealth zakat and tax. Community's positive attitude toward the obligation of paying wealth zakat and tax is rooted from their knowledge, awareness, faith, and belief, that it will bring benefits to themselves as well as other people, which eventually transform into public prosperity. The questionnaire results also prove that subjective norm to pay tax is not influenced by family/friend or zakat/tax officer. This indicates that the respondents' level of religiosity is fairly high, because they seek rewards solely from Allah, and they believe that failure to pay the wealth zakat when they are able to will lead to sins. Perceived behavioral control in form of investigation and sanction for taxpayers who don't pay their tax also play critical role. The research results prove that both are highly influential to respondents' intention to pay tax.

The research results are expected to add to the research literatures regarding inter-generational perception toward wealth zakat and tax in digital era to be scrutinized from the Theory of Planned Behavior. Furthermore, the results can also serve as an input to taxation regulator to sensitize more about the regulations they made, as until now, there are still many citizens who are unaware that the zakat they paid through amil zakat institution can be used as deductor to their taxable income, which will decrease the amount of tax they will have to pay. Amil zakat institutions should be more professional, trust-worthy, able to collect data as well as reach out wider mustahiks in the future. This was expressed by some respondents, who still chose to pay their wealth zakat directly to their nearby mustahik, as they said that those mustahiks were never reached out by any amil zakat institution. To reduce poverty and increase 
social welfare, good collaboration between elements of community, amil zakat institution, and government is crucial. Respondents who chose to pay directly their wealth zakat to mustahik can act as a temporary relief to complement the limitations of the amil zakat institutions which still cannot reach out all the needing mustahiks. This actually supports the amil zakat institution's works, which currently are still unable to distribute the wealth zakat to all mustahiks in all regions.

The amil zakat institution can also undertake various educative sensitizations both directly and indirectly through social media, to remind the Muslims that paying wealth zakat is compulsory for those who have met the criteria, as well as about the method to calculate the amount of wealth zakat, as well as coverage of wealth zakat as set forth in the Qur'an and hadits. Nevertheless, these generations also understood about the obligation to pay the zakat to eight groups of mustahiks as set forth by the religion.

It is recommended for taxation regulator to perform a more user friendly sensitization through various social media regarding various taxation regulations that have been made, so as to ensure that more people are updated about such information. This is even more relevant since almost all the existing generations are actually active in and familiar of using the internet and social media. It is hoped to bring positive impacts toward receipt of wealth zakat and tax in order to create social welfare for all Indonesian people. In addition, tax investigation needs also to be performed randomly and intensively to capture individual taxpayers who still don't pay their tax. Sanctions must be implemented firmly and consistently. 


\section{Conclusion}

The research aims to implement the theory of planned behavior to predict respondent's intention to participate in offering wealth zakat and tax payment. The descriptive statistics results show that respondents understood that zakat is religious obligation; agreed that paying wealth zakat and tax might help reducing poverty and improving social welfare; more respondents knew that wealth zakat could be used as deducting factor in tax calculation; agreed that they would still pay tax regardless whether the wealth zakat and tax can be a deducting factor for their taxed income or not; respondents paid the wealth zakat directly to mustahik for reasons such as its primacy status, easiness, and proximity/location; other respondents paid their wealth zakat via transfer to the amil zakat institution's account, for its comfort (online payment), professionalism/ trustworthiness of the institution. Meanwhile, the analysis results using PLS revealed that attitude, subjective norm, and behavioral control influence one's intention to pay wealth zakat and tax; furthermore, behavioral intention affects actual behavior in paying wealth zakat and tax.

The research results are expected to add to the research literatures regarding inter-generational perception toward wealth zakat and tax in digital era to be scrutinized from the Theory of Planned Behavior. Furthermore, the results can also serve as an input to taxation regulator to sensitize more about the regulations they made, as until now, there are still many citizens who are unaware that the zakat they paid through amil zakat institution can be used as deductor to their taxable income, which will decrease the amount of tax they will have to pay. Amil zakat institutions should be more professional, trust-worthy, able to collect data as well as reach out wider mustahiks in the future.

In the end, in order to achieve a better social welfare, through zakat and tax, all parties related should contribute and collaborative actively. 
As based on this research, it is found that these three items (attitude, subjective norm, and perceived behavioral control) have significant impact on societies' intention to pay zakat and tax continuously. Zakat institution and tax regulator are required to execute effective socialization of regulation related to zakat and tax (including the information that zakat can be deducted from PKP if they pay the zakat to LAZ) to the society more aggressively in order to generate those three aspects of theory of planned behavior. The socialization can be maximized by using digital socialization through many kinds of social media used by citizen. Moslem citizen is also required to have a better initiative to increase the awareness and compliance to pay zakat and tax in order to be more engaged in generating social welfare to the society. The research supports the argument that in regulated environment like zakat and tax, the theory of planned behavior can still effectively explain the behavior of zakat and tax compliance. 


\section{References}

Ajzen, Icek. \& Fishbein, M. (1980). Understanding Attitudes and Predicting Social Behavior. Englewood Cliffs, NJ: Prentice-Hall.

Ajzen, Icek. (1985). "From intentions to actions: a theory of planned behavior", in Kuhl, J. And Beckman, J. (Eds), Action-control: From Cognition to Behavior, Springer, Heidelberg, pp. 11-39.

Ajzen, Icek. (1991). The Theory of Planned Behavior: Organizational Behavior and Human Decision Processes (Vol. 50, 179-211). University of Massachusetts at Amhest: Academic Press. Inc.

Ajzen, Icek. (2002). Constructing a TPB Questionnaire: Conceptual and Methodological Consideration. September (Revised January 2006). Alpriyamah, Qurotu Uyun. \& Adityawarman. (2017). Analisis FaktorFaktor yang Mempengaruhi Perilaku Kepatuhan (Compliance Behavior) Pembayaran Zakat Perdagangan (Studi Kasus Pengusaha Muslim Batik di Kota Pekalongan Tahun 2017). Diponegoro Journal of Accounting Vol. 6( 3), pp. 1-13.

Lesmana, Desy., Panjaitan, Delfi., and Maimunah, Mutiara. (2017). Tax Compliance Ditinjau dari Theory of Planned Behavior (TPB): Studi Empiris Pada Wajip Pajak Orang Pribadi dan Badan yang Terdaftar Pada KPP di Kota Palembang. Jurnal InFestasi Vol. 13(2), pp. 354366.

Republik Indonesia. (2011). Undang-Undang Republik Indonesia Nomor 23 Tahun 2011 tentang Pengelolaan Zakat.

Republik Indonesia. (2012). Peraturan Dirjen Pajak Nomor 15 Tahun 2012 tentang Perubahan Peraturan Dirjen Pajak Nomor 33 Tahun 2011 tentang Badan/Lembaga yang Dibentuk atau Disahkan Oleh Pemerintah yang Ditetapkan Sebagai Penerima ZakatAtau Sumbangan Keagamaan Yang Sifatnya Wajib yang Dapat Dikurangkan dari Penghasilan Bruto. 
Saad, Ram Al Jaffri., \& Haniffa, Roszaini. (2014). Determinants of Zakah (Islamic tax) Compliance Behavior. Journal of Islamic Accounting and Business Research, Vol.5(2), pp.182-193. Emerald Group Publishing Limited, DOI 10.1108/JIABR-10-2012-0068.

Sekaran, Uma. (2003). Research Methods for Business: A Skill Building Approach (4th ed). New York: John Willey and Sons.

Wiedmer, Terry. (2015). Generations Do Differ: Best Practices in Leading Traditionalists, Boomers, and Generations X, Y, and Z. The Delta Kappa Gamma Bulletin: International Journal for Professional Educators.

Yusuf, Muhammad., \& Ismail, Tubagus. (2017). Pengaruh Pengetahuan Pajak, Pengetahuan Zakat, dan Sikap terhadap Kepatuhan Wajib Pajak Muslim. Jurnal Ilmiah Ilmu Administrasi Transparansi, Universitas Mercu Buana Jakarta, Vol. 9(2). 
Vol. 3 No. 3, September - December 2018 


\section{Shirkah Author Guidelines}

Shirkah currently offers two routes to submit manuscripts. We highly recommend to submit the articles which are made using OJS (Open Journal System). Feel free register as author soon through visiting http:// shirkah.or.id/index.php/home/user/register. The authors may directly send their manuscripts, along with their resume, to shirkahiainsurakarta@ gmail.com. Please prepare your manuscripts, using following guidelines:

1. Manuscript must be written in English. Submitted articles should not have been published or be under review for publication with another journal.

2. Manuscript's length is about $15-20$ pages, typed in one-half spaced on A4-paper size.

3. Manuscript must include an $150-200$ word abstract and keywords.

4. Manuscript must be arranged as follows: Title, Name of Author, E-mail address, Abstract, Keywords, Introduction (including method if any), Discussion, Conclusion, References.

5. Manuscript's titles not more than ten words.

6. Manuscript must be submitted in Microsoft Word or RTF.

7. Arabic words should be transliterated according to the style of International Journal of Middle Eastern Studies.

8. Manuscript references are preferably derived from the up-to-date references.

9. The author's resume should be submitted separately, consisting of at least full name, institutional address, phone number, areas of studies, and recent publications (if any).

10. Shirkab use APA Style 6th edition (2010) as reference format writing. We suggest the use of a reference manager software such as Mendeley, Zotero, and Endnote at templating the citation style. APA Style to be used is as follows: 


\section{Book with single author}

Swann, G. M. Peter. (2014). The Economics of Innovation an Introduction. Cheltenhum \& Northampton: Edward Elgar.

in-text citation: (Swann, 2014)

\section{Articles in reference books}

Alatas, S. F. (2006). Islam and the Science of Economics in Abu Rabi', I.M. The Blackwell Companion to Contemporary Islamic Thought. USA: Willey-Blackwell (pp. 587-606).

in text citation: (Alatas, 2006)

\section{E-Book}

Hackett, Rosalind (2007). "Religous Dimentions of War and Peace: Introduction." Dalam Gerrie ter Haar dan Yoshio Tsuruoka (Ed.), Religion and Society: An Agenda for the 21st Century (h. 3-6). Retrieved from http:// brill.nl.

in text citation: (Hackett, 2006)

\section{Master's thesis, from a commercial database}

McNieI, D. S. (2006). Meaning through narrative: A personal narrative discussing growing up with an alcoholic mother (Master's thesis). Available from ProQuest Dissertations and Theses database. (UMI No. 1434728)

in text citation: (Mc Niel, 2006)

\section{Doctoral dissertation, from an institutional database}

Adams, R. J. (1973). Building a foundation for evaluation of instruction in higher education and continuing education (Doctoral dissertation). Retrieved from http://www.ohiolink.edu/etd/

in text citation: (Adams, 1973) 


\section{Doctoral dissertation, from the web}

Bruckman, A. (1997). MOOSE Crossing: Construction, community, and learning in a networked virtual world for kids (Doctoral dissertation, Massachusetts Institute of Technology). Retrieved from http:/www-static. cc.gatech.edu/--asb/thesis/

in text citation: (Bruckman, 1997)

\section{Journal article with No DOI}

Bourkhis, K., and Nabi, M. S. (2013). Islamic and conventional banks' soundness during the 2007-2008 financial crisis. Journal Metrics, 22(2), 68-77.

in-text citation: (Bourkhis \& Nabi, 2013).

\section{Journal article with DOI}

Ichwan, M. (2012). The Local Politics Of Orthodoxy: The Majelis Ulama Indonesia in the Post-New Order Banten. Journal Of Indonesian Islam, 6(1), 166-194. doi:http://dx.doi.org/10.15642/JIIS.2012.6.1.166-194

In text citation : (Ichwan, 2012)

\section{Abstract as citation}

Hasan, N. (2012). Islamist Party, Electoral Politics And Da'wah Mobilization Among Youth : The Prosperous Justice Party (PKS) in Indonesia. Journal of Indonesian Islam, 6(1), 17-47. Abstract from http:// jiis.uinsby.ac.id/index.php/jiis/article/view/97

in text citation : (Hasan, 2012)

\section{Mass media article}

Sahal, Akhmad (2014, March 2). Kiai Sahal dan Realisme Fikih.Tempo Magazine, p. 120.

in text citation : (Sahal, 2014) 


\section{Research report}

Fisher, B. S., Cullen, F. T., \& Turner, M. G. (2000). The Sexual Victimization of College Women. Research Report.

in text citation : (Fisher, Cullen, Turner, 2000)

\section{Monograph}

Routray, Bibhu Prasad (2013), National Security Decision-Making in India (RSIS Monograph No. 27). Singapura: Rajaratnam School of International Studies.

in text citation : (Routray, 2013)

\section{Proceeding article}

Sudibyakto, Hizbaron, D.R., \& Jati, R (Ed.) (2009), Proceeding International Seminar Disaster Theory, Research and Policy. International seminar held by Sekolah Pascasarjana, Universitas Gajahmada, Yogyakarta, 8-9 Desember 2009.

in text citation : (sudibyakto and Jati, 2009)

\section{Paper conference/seminar/symposium}

Janutama, Herman Sinung (2011). "Kraton dan Hubungan Antar Agama." Paper presented in Seminar Kraton dan Panatagama held by Center for the Study of Islam and Social Transformation (CISForm), Yogyakarta, 17 November.

$$
\text { in text citation :(Janutama, 2011) }
$$

\section{Online article in web}

Shiva, (2006, February). Bioethics: A Third World Issue. Native-web. Diperoleh dari http://www.nativeweb.org/ pages/legal/shiva.html 


\section{in text citation : (Shiva, 2006)}

\section{Online research report}

Kessy, S. S. A., \& Urio, F M. (2006). The contribution of microfinance institutions to poverty reduction in Tanzania (Research Report No. 06.3). Retrieved from Research on Poverty Alleviation website: http://www. repoa.or.tz /documents_storage/Publications/Reports/06.3_Kessy_and_ Urio.pcif

in text citation : (kessy and urion, 2006)

\section{Holy book}

Qur an, $2(25)$

In text citation : (Q. al-Baqarah 2:25).

\section{Encyclopaedia}

Graycar, Adam (1992). Social Welfare Policy. Dalam Mary Hawkesworth dan Maurice Kogan (Ed.), Encyclopedia of Government and Politics (Vol. 1). London: Routledge.

in text citation : (Graycar, 1992)

\section{Interview}

Sultan Hamengkubuwono X (interview, 2011, April 19)

in text citation : (Hamengkubuwono, 2011)

\section{Documentary film}

Steijlen, Fridus (2008). A Day in the Life of Indonesia [documentary film, 58 minutes]. Leiden: KITLV Press.

in text citation : (Steijlen, 2008) 
Vol. 3 No. 3, September - December 2018 